Michał Kliński', Oskar Komisarek²

\title{
Potencjalne geny predysponujące do rozwoju prognatyzmu żuchwy - przegląd piśmiennictwa
}

\author{
Potential genes predisposing to the development of mandibular prognathism - \\ a review of the literature
}

\begin{abstract}
1 Studenckie Koło Naukowe Ortopedii Szczękowej i Ortodoncji, Uniwersytet Medyczny im. Karola Marcinkowskiego w Poznaniu Students Scientific Association of Maxillary Orthopaedics and Orthodontics, Poznan University of Medical Sciences ${ }^{2}$ Katedra i Klinika Ortopedii Szczękowej i Ortodoncji, Uniwersytet Medyczny im. Karola Marcinkowskiego w Poznaniu Chair and Department of Maxillofacial Orthopaedics and Orthodontics, Poznan University of Medical Sciences
\end{abstract}

DOI: http://dx.doi.org/10.20883/df.2020.16

\begin{abstract}
STRESZCZENIE
Prognatyzm żuchwy to morfologiczna wada doprzednia charakteryzująca się przerostem żuchwy, wklęsłym profilem, doprzednio ustawioną wargą dolną w stosunku do górnej. Pacjenci dotknięci progenią często zmagają się z trudnością w prawidłowej artykulacji, zaburzonym torem oddychania, mową, żuciem, nieprawidłową pracą stawu skroniowo-żuchwowego oraz złym stanem zdrowia psychicznego. Wada ta w skali świata znacznie częściej występuje w populacji azjatyckiej. Wielokrotnie próbowano wskazać istotne czynniki etiologiczne, sugerując, że podłoże genetyczne może odgrywać najważniejszą rolę. Wnioski te popierano analizą rodowodów. Dzięki postępowi technologicznemu i możliwości sekwencjonowania ludzkiego genomu udało się ustalić i wskazać miejsca locus dla genów prawdopodobnie odpowiadających za wystąpienie wady w badanej grupie. Nowoczesne badania asocjacyjne całego genomu pozwalają na badanie nie tylko w oparciu o rodowód, lecz także dużych niespokrewnionych grup kontrolnych i badawczych. Progenia jest wadą uwarunkowaną poligenetycznie, a indywidualne sekwencje genów oraz warianty alleli mogą być charakterystyczne dla konkretnej populacji, a nawet wyjątkowe dla danej rodziny.
\end{abstract}

Słowa kluczowe: prognatyzm żuchwy, geny kandydackie, warianty genetyczne, III klasa angle, dziedziczenie.

\section{ABSTRACT}

The prognathism of the mandible is a morphological anterior defect, characterized by mandibular hypertrophy, a concave profile and a lower lip positioned in front to the upper lip. Patients affected by prognathism often struggle with difficulty in correct articulation, disturbed breathing pathways, speech, chewing, abnormal work of the temporomandibular joint and poor mental health. Worldwide this defect is much more common in the Asian population. There have been many attempts to indicate important etiological factors, suggesting that the genetic basis may play the most important role. These conclusions were supported by an analysis of pedigrees.

Thanks to technological progress and the possibility of sequencing the human genome, it was possible to determine and indicate the locus location for genes that are probably responsible for the occurrence of the defect in the studied group. Modern genome-wide association studies allow for the study of not only pedigree but also of large unrelated control and research groups. Mandibular prognathism is a poligenetically determined defect, and individual gene sequences and allele variants may be population-specific or even unique to a given family.

Keywords: mandibular prognathism, candidate genes, genetic variants, angle class III, inheritance.

\section{Wstęp}

Prognatyzm żuchwy (mandibular prognathism) - progenia - jest morfologiczną wadą doprzednią charakteryzującą się przerostem żuchwy, występującą często z towarzyszącym w wymiarze poprzecznym i przednio-tylnym niedorozwojem szczęki, wklęsłym profilem twarzy, wysuniętą przed pole biometryczne bródką, wygładzoną bruzdą wargowo-bródkową oraz doprzednio usta- wioną w stosunku do wargi górnej wargą dolną. W przypadku retruzji siekaczy dolnych może dojść do zwiększenia napięcia wargi dolnej. A w przypadku pacjentów wysokokątowych dodatkowo dochodzi do zwiększenia wysokości dolnego piętra twarzy. Wewnątrzustnie najczęściej stwierdza się III klasę Angle'a, III klasę kłową, ujemny nagryz poziomy oraz pionowy [1]. 
Wada ta ogranicza prawidłowe funkcjonowanie organizmu - zaburza funkcje żucia, oddychania oraz artykulacji. Wpływa niekorzystnie na staw skroniowo-żuchwowy (SSŻ), powodując jego nadmierne obciążenie prowadzące do powstania patologii SSŻ. Zwiększa ryzyko powstania urazów zębów oraz pogarsza stan psycho-społeczny pacjenta [2].

Wady doprzednie nie zawsze widoczne są we wczesnym dzieciństwie, najczęściej pojawiają się w okresie intensywnego wzrostu, nasilając w okresie dojrzewania [3].

Przodożuchwie morfologiczne występuje w populacjach na całym świecie, ale częściej występuje w populacjach azjatyckich [4]. Charakter wady szkieletowej jest bardziej nasilony u pacjentów w populacjach chińskiej, koreańskiej i japońskiej niż obserwowane u rasy kaukaskiej [5, 6].

Przyczyna prognatyzmu żuchwy jest wciąż niewyjaśniona. Wada wiązana była z różnymi czynnikami środowiskowymi, takimi jak: powiększenie migdałków, trudności w oddychaniu przez nos, postawa ciała, zaburzenia endokrynologiczne, urazy i porody instrumentalne [7, 8]. Wiele dowodów wskazuje, że progenia występuje u obu bliźniąt i dziedziczy się w rodzinach, co oznacza, że czynniki genetyczne odgrywają ważną rolę $w$ jej etiologii. Najbardziej znanym przykładem cechy objawiającej się fenotypowo nadmiernym wzrostem żuchwy jest tzw. „żuchwa Habsburgów”, która stała się swoistą cechą królewskiego rodu [9]. W celu opisania tego problemu przeprowadzono wiele badań, jednak wyniki nie są spójne ani jednolite, co sprawia, że etiologia wciąż pozostaje niewyjaśniona. Wśród sugerowanych sposobów dziedzi- czenia występowało wiele wariantów: autosomalny-dominujący, autosomalny-recesywny, mono-, poligenetyczny, jednak dzięki postępowi w dziedzinie genetyki możliwe jest aktualnie określenie genów kandydackich [4, 10].

Celem pracy jest przedstawienie na podstawie piśmiennictwa wariantów genów kandydackich predysponujących do powstawania prognatyzmu żuchwy.

\section{Materiał i metoda}

Dokonano przeglądu literatury z ostatnich 15 lat zawartej w bazie PubMed, w oparciu o słowa kluczowe: mandibular prognathism, candidate genes, genes, linkage analysis, class III malocclusion, GWAS, WES.

Kryteria kwalifikacji: analizowano wyłącznie prace napisane w języku angielskim. Do przeglądu piśmiennictwa zostały zakwalifikowane prace wskazujące nowe loci, które istotnie mogą być związane z wystąpieniem prognatyzmu żuchwy lub geny ulegające najprawdopodobniej ekspresji w pobliżu locus wskazanego wcześniej przez innych autorów. Prace musiały uwzględniać badanie genomu ludzkiego metodami sekwencjonowania genetycznego oraz analizę sprzężeń. Prace bazujące na modelach komórkowych i zwierzęcych oraz przeglądy piśmiennictwa zostały wykluczone $z$ analizy.

Zakwalifikowane prace przedstawiono $w$ formie tabelarycznej (Tabela 1). Zwrócono szczególną uwagę na grupę badaną, gen oraz jego locus i metodę, jaką potwierdzono występowanie genu mogącego wpłynąć na powstanie prognatyzmu żuchwy u badanych pacjentów. 


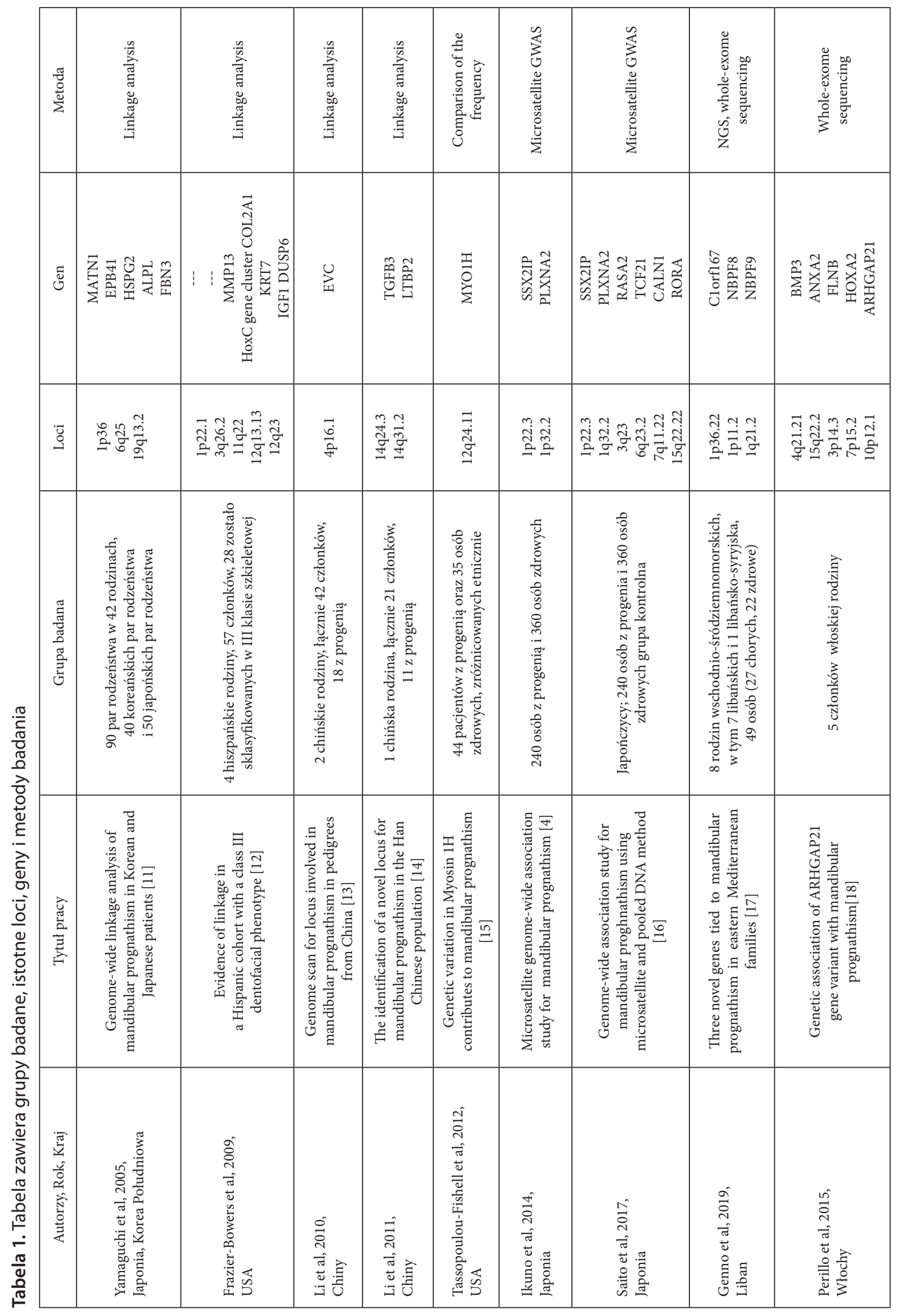




\section{Wyniki}

Na podstawie uwzględnionych w badaniu prac zebrano potencjalne miejsca locus istotne dla rozwoju prognatyzmu żuchwy oraz wyszczególniono również geny najprawdopodobniej ulegające ekspresji w pobliżu wskazanego locus. Informacje te przedstawione są w formie tabelarycznej (Tabela 2).

Tabela 2. Istotne loci, geny i produkty białkowe ich ekspresji

\begin{tabular}{|c|c|c|}
\hline Locus & $\begin{array}{l}\text { Geny ulegające } \\
\text { ekspresji w pobliżu } \\
\text { wskazanego locus }\end{array}$ & $\begin{array}{c}\text { Nazwa kodowanego } \\
\text { białka }\end{array}$ \\
\hline $1 p 36$ & $\begin{array}{l}\text { MATN1 } \\
\text { EPB41 } \\
\text { HSPG2 } \\
\text { ALPL }\end{array}$ & $\begin{array}{c}\text { Matrylina } 1 \\
\text { Białko wiążące błony } \\
\text { erytrocytu } 4.1 \\
\text { Proteoglikan siarczanu } \\
\text { heparanu } 2 \\
\text { Fosfataza alkaliczna }\end{array}$ \\
\hline $6 q 25$ & --- & --- \\
\hline $19 q 13.2$ & FBN3 & Fibrylina-3 \\
\hline $1 \mathrm{p} 22.1$ & --- & --- \\
\hline $3 q 26.2$ & --- & --- \\
\hline $11 q 22$ & MMP13 & $\begin{array}{c}\text { Metalopeptydaza } \\
\text { macierzy } 13\end{array}$ \\
\hline $12 q 13.13$ & $\begin{array}{l}\text { HoxC gene cluster } \\
\text { COL2A1 } \\
\text { KRT7 }\end{array}$ & $\begin{array}{c}\text { Konserwatywne } \\
\text { czynniki wzrostu } \\
\text { Łańcuch alfa } 1 \text { kolagenu } \\
\text { typu II } \\
\text { Keratyna } 7\end{array}$ \\
\hline $12 q 23$ & $\begin{array}{c}\text { IGF1 } \\
\text { DUSP6 }\end{array}$ & $\begin{array}{c}\text { Insulino podobny } \\
\text { czynnik wzrostu typu } 1 \\
\text { Fosfataza } 6\end{array}$ \\
\hline $4 p 16.1$ & EVC & --- \\
\hline $14 q 24.3$ & TGFB3 & $\begin{array}{c}\text { Transformujący czynnik } \\
\text { wzrostu-beta } 3\end{array}$ \\
\hline $14 q 31.2$ & LTBP2 & $\begin{array}{l}\text { Rodzina białek } \\
\text { wiążących latentny } \\
\text { transformujący czynnik } \\
\text { wzrostu (TGF) -beta }\end{array}$ \\
\hline $12 q 24.11$ & MYO1H & Miozyna klasy I, \\
\hline $1 \mathrm{p} 22.3$ & SSX2IP & $\begin{array}{c}\mathrm{X} \text { breakpoint } 2 \\
\text { interacting protein }\end{array}$ \\
\hline $1 q 32.2$ & PLXNA2 & Pleksyna-A2 \\
\hline $3 q 23$ & RASA2 & $\begin{array}{c}\text { Aktywator } 2 \text { białka } \\
\text { Ras p21 }\end{array}$ \\
\hline $6 q 23.2$ & TCF21 & $\begin{array}{c}\text { Czynnik transkrypcyjny } \\
21\end{array}$ \\
\hline $7 q 11.22$ & CALN1 & Kalneuryna 1 \\
\hline $15 q 22.22$ & RORA & $\begin{array}{l}\text { Receptor sierocy } \\
\text { powiązany z RAR } \\
\text { [receptorem kwasu } \\
\text { retinowego] }\end{array}$ \\
\hline $1 p 36.22$ & C1orf167 & --- \\
\hline $1 \mathrm{p} 11.2$ & NBPF8 & $\begin{array}{c}\text { Putative neuroblastoma } \\
\text { breakpoint family } \\
\text { member } 8\end{array}$ \\
\hline
\end{tabular}

\begin{tabular}{|l|c|c|}
\hline $1 \mathrm{q} 21.2$ & NBPF9 & $\begin{array}{c}\text { Putative neuroblastoma } \\
\text { breakpoint family } \\
\text { member } 9\end{array}$ \\
\hline $4 \mathrm{q} 21.21$ & BMP3 & $\begin{array}{c}\text { Białko morfogenetyczne } \\
\text { kości 3 }\end{array}$ \\
\hline $15 \mathrm{q} 22.2$ & ANXA2 & Aneksyna A2 \\
\hline $3 \mathrm{p} 14.3$ & FLNB & Filamina B \\
\hline $7 \mathrm{p} 15.2$ & HOXA2 & HomeboxA2 \\
\hline $10 \mathrm{p} 12.1$ & ARHGAP21 & $\begin{array}{c}\text { Rho GTP-aza aktywująca } \\
\text { białko 21 }\end{array}$ \\
\hline
\end{tabular}

\section{Dyskusja}

Celem pracy było zebranie wszystkich genów predysponujących do rozwoju prognatyzmu żuchwy. Wyniki zebrane w badaniu wskazują czynniki genetyczne istotnie powiązane z tą nieprawidłowością. W piśmiennictwie na podstawie rodowodów sugerowano wiele schematów dziedziczenia, choć najczęściej pojawia się autosomalny dominujący z niepełną penetracją $[7,21]$. Wydaje się, że wada ma podłoże wieloczynnikowe, poligenetyczne.

Istotnym elementem wydaje się zróżnicowanie pod względem etnicznym, gdyż dana grupa etniczna posiada własne charakterystyczne warianty alleli w zależności od pochodzenia. Niektóre ze wskazywanych wariantów sekwencji występujące w populacjach azjatyckich, gdzie występowanie prognatyzmu żuchwy wykazuje najwyższą frekwencję, a nie występują wśród osób rasy kaukaskiej.

W badaniach na zwierzętach udowodniono, że rozwój żuchwy jest zależny od poszczególnych małych jej obszarów, gdzie ekspresja białek niezależnie [7]. Sama kość odpowiada na działające na nią czynniki mechaniczne i w ten sposób może ulegać zmianom morfologicznym. W rozwoju twarzoczaszki nie bez znaczenia pozostaje wpływ siły generowanej przez mięśnie żucia, która zmienia się dynamicznie przez całe życie. Czynniki mechaniczne działające na kość wywołują lokalne zmiany w jej metabolizmie, wpływając na ukierunkowanie jej wzrostu. Najnowsze możliwości badań genetycznych pozwalają na określenie sekwencji całego genomu, a w oparciu o te sekwencje przeprowadzać duże badania asocjacyjne, jak genome wide association study (GWAS) czy whole exome sequencing (WES), w których obecność wielu polimorfizmów pojedynczych nukleotydów jest analizowane w odniesieniu do bardzo dużych grup badawczych i kontrolnych, które nie są ze sobą spokrewnione [21, 22]. Badania te dostarczają ogromnej ilości informacji, co powoduje trudności w określeniu, czy dana sekwencja jest istotnie powiązana z rozwojem wady lub czy białko ulegają- 
ce ekspresji jest istotne dla określonego fenotypu. Biorąc pod uwagę wszystkie czynniki, nie możemy zapomnieć o działaniu czynników epigenetycznych, które w znacznym stopniu wpływać mogą na ekspresję danego genu. Wiele zmian w ekspresji genów może być spowodowane czynnikami środowiskowymi, zmianami zachodzącymi na poziomie epigenetycznym regulującymi proces ekspresji, jak metylacja DNA, acetylacja histonów czy wyciszanie genów przez miRNA.

Identyfikacja wpływu genetycznego na fenotyp pomoże zrozumieć nam molekularne regulacje odpowiedzialne za rozwój twarzoczaszki i pozwoli poprawić efektywność leczenia pacjentów z wadami zębowymi.

Z klinicznego punktu widzenia, jeśli ortodonta mógłby przewidzieć, czy pacjent posiada silne czynniki do nadmiernego rozwoju żuchwy, mógłby wcześniej dobrać odpowiednie leczenie profilaktyczne. Najnowsze badania genetyczne umożliwiają coraz dokładniejsze zrozumienie tych interakcji, co pozwoli przewidywać rozwój twarzoczaszki i jak najlepiej zaplanować leczenie dla pacjenta, głównie poprzez profilaktykę wystąpienia wady.

\section{Wnioski}

Spośród wskazanych prac nie można jednoznacznie określić konkretnego locus lub genu odpowiedzialnego za rozwój prognatyzmu żuchwy. Każda populacja posiada indywidualną częstość występowania wariancji danych alleli, a nawet własne wyjątkowe sekwencje w obrębie danej rodziny. Zebrane wyniki wydają się sugerować jednak istotne powiązanie prognatyzmu żuchwy z mutacjami występującymi w obrębie chromosomu 1. Uwarunkowania rozwoju przodożuchwia morfologicznego są z pewnością wielogenowe i zależeć mogą również od czynników epigenetycznych oraz środowiskowych, które nie zostały uwzględnione $w$ tej pracy. Znalezienie szlaku łączącego istotne geny wydaje się być najbardziej obiecującym kierunkiem badania, co powinno skłonić badaczy do wykonywania badań bazujących na pełnych badaniach asocjacyjnych genomu.

\section{Oświadczenia}

\section{Oświadczenie dotyczące konfliktu interesów}

Autorzy deklarują brak konfliktu interesów w autorstwie oraz publikacji pracy.

\section{Źródła finansowania}

Autorzy deklarują brak źródeł finansowania.

\section{Piśmiennictwo}

[1] Proffit W, Phillips C, Dann C. Who seeks surgical-orthodontic treatment? Int J Adult Orthodon Orthognath Surg 1990;5:153-60.

[2] Proff P. Malocclusion, mastication and the gastrointestinal system: a review. J Orofac Orthop. 2010; 71:96-107.

[3] Shira R, Neuner O. Surgical correction of mandibular prognathism. Oral Surg Oral Med Oral Pathol 1976;42:415-30.

[4] Ikuno K, Kajii TS, Oka A, et al. Microsatellite genomewide association study for mandibular prognathism. Am J Orthod Dentofacial Orthop 2014;145:757-762.

[5] Singh GD, McNamara JA Jr, Lozanoff S. Craniofacial heterogeneity of prepubertal Korean and European-American subjects with Class III malocclusions: procrustes, EDMA, and cephalometric analyses. Int J Adult Orthodon Orthognath Surg 1998;13:227-240.

[6] Ishii N, Deguchi T, Hunt NP. Craniofacial differences between Japanese and British Caucasian females with a skeletal Class III malocclusion. Eur J Orthod 2002;24:493-499.

[7] Doraczynska-Kowalik, Anna MD; Nelke, Kamil H. DMD, PhD; Pawlak, Wojciech DMD, PhD; Sasiadek, Maria M. MD, PhD; Gerber, Hanna DMD, PhD. Genetic Factors Involved in Mandibular Prognathism Journal of Craniofacial Surgery: July 2017 ,Vol. 28( 5) 422-431].

[8] Jena AK, Duggal R, Mathur VP, et al. Class-III malocclusion: genetics or environment? A twins study. J Indian Soc Pedod Prev Dent 2005;23:27-30.

[9] Wolff G, Wienker TF, Sander H. On the genetics of mandibular prognathism: analysis of large European noble families. J Med Genet 1993;30:112-116.

[10] Xue F, Wong RWK, Rabie ABM. Genes, genetics, and Class III malocclusion. Orthod Craniofac Res 2010;13:69-74.

[11] Yamaguchi T, Park SB, Narita A, Maki K, Inoue I. 2005. Genome-wide link- age analysis of mandibular prognathism in Korean and Japanese patients. J Dent Res. 84(3):255-259.

[12] Frazier-Bowers S, Rincon-Rodriguez R, Zhou J, Alexander K, Lange E. 2009. Evidence of linkage in a Hispanic cohort with a class III dentofacial phenotype. J Dent Res. 88(1):56-60.

[13] Li Q, Zhang F, Li X, Chen F. 2010. Genome scan for locus involved in mandibular prognathism in pedigrees from China. PloS One. 5(9):e12678.

[14] Li Q, Li X, Zhang F, Chen F. 2011. The identification of a novel locus for man- dibular prognathism in the Han Chinese population. J Dent Res. 90(1):53-57.

[15] Tassopoulou-Fishell M, Deeley K, Harvey E, Sciote J, Vieira A. Genetic variation in Myosin $1 \mathrm{H}$ contributes to mandibular prognathism. Am J Orthod Dentofacial Orthop 2012;141:51-9.

[16] Saito F, Kajii TS, Oka A, Ikuno K, lida J, Genome-wide association study for mandibular prognathism using microsatellite and pooled DNA method. Am J Ortho Dentofacial Orthop 2017;152;382-388. 
[17] Genno PG, Nemer GM, Zein Eddine SB, Macari AT, Ghafari JG. Three novel genes tied to mandibular prognathism in eastern Mediterranean families. Am J Orthod Dentofacial Orthop. 2019 Jul;156(1):104-112.

[18] Perillo L, Monsurro A, Bonci E, Torella A, Mutarelli $M$, Nigro V. Genetic association of ARHGAP21 gene variant with mandibular prognathism. J Dent Res 2015;94:569-76.

[19] Vandepoele K, Van Roy N, Staes K, Speleman F, Van Roy F. A novel gene family NBPF: intricate structure generated by gene duplications during primate evolution. Mol Biol Evol 2005;22:2265-74.

[20] Da Fontoura CS, Miller SF, Wehby GJ, et al. Candidate gene analyses of skeletal variation in malocclusion. J Dent Res 2015;94:913-920.

[21] Moreno Uribe LM, Miller SF. Genetics of the dentofacial variation in human malocclusion. Orthod Craniofac Res 2015;18(Suppl 1):91-9.
[22] Manolio TA. Study designs to enhance identification of genetic factors in healthy aging. Nutr Rev. 2007; 65(12 Pt 2):S228-33.

Zaakceptowano do edycji: 2020-10-06 Zaakceptowano do publikacji: 2020-10-06

\section{Adres do korespondencji:}

Michał Kliński

ul. Karpia $17 \mathrm{~B} / 9$

61-619 Poznań

tel. 664-771-963

e-mail:klinskimichal@gmail.com 